\section{ASSESSMENT OF THE ACCURACY AND PRECISION OF MYRTKNET REAL-TIME SERVICES}

Muhammad Afia Amirrudina, Ami Hassan Md Dina,b*, Nur Adilla Zulkiflia, Muhammad Asyran Che Amatc, Mohammad Hanif Hamdena

aGeomatics Innovation Research Group (GnG), bGeoscience and Digital Earth Centre (INSTEG), Faculty of Built Environment and Surveying, Universiti Teknologi Malaysia, 81310 UTM Johor Bahru, Johor, Malaysia

'Geodetic Survey Division, Department of Survey and Mapping Malaysia (DSMM), Jalan Sultan Yahya Petra, 50578 Kuala Lumpur, Wilayah Persekutuan Kuala Lumpur, Malaysia
Article history

Received

1 June 2019

Received in revised form

23 November 2020

Accepted

3 December 2020

Published online

17 December 2020

*Corresponding author: amihassan@utm.my

\section{Graphical abstract}

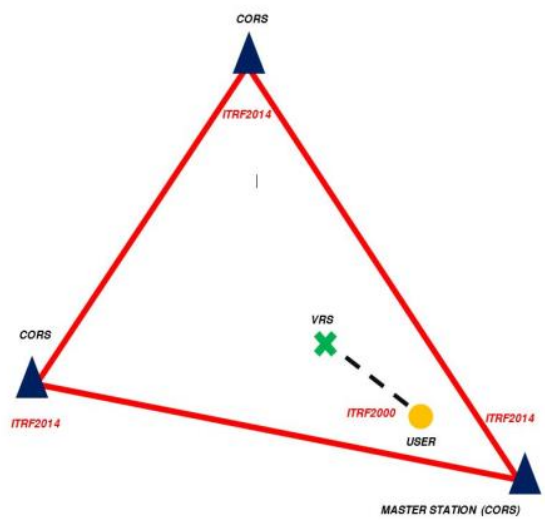

\begin{abstract}
From a network of ninety-six (96) Continuously Operating Reference Stations (CORS), the Department of Survey and Mapping Malaysia (DSMM) has developed a reliable real-time data streaming service known as the Malaysia Real-Time Kinematic GNSS Network (MyRTKnet). MyRTKnet is now operating on Leica SpiderNet system that is configured to provide coordinate to users in Geocentric Datum of Malaysia 2000 (GDM2000). As the name implied, GDM2000 is a geocentric datum for Malaysia, developed based upon the International Terrestrial Reference Frame (ITRF) 2000 or ITRF2000. One could argue that the quality of coordinates provided by MyRTKnet are less optimal as the latest realisation of ITRF at present is ITRF2014. This study aims to investigate the accuracy and precision of the resultant coordinates from MyRTKnet real-time services through a comparison with the control-quality coordinates from a network of post-processed data at some independent points for positioning purpose. Meanwhile for mapping purpose, the coordinates from Network RealTime Kinematic (NRTK) at selected Cadastral Reference Marks (CRM) points were compared with their known values. The results show that the observed points in ITRF2000 move approximately $37 \mathrm{~cm}$ away from the points in ITRF2014 due to the constant movement of Sundaland Block. Meanwhile for the assessment of NRTK technique, there is no significant displacement for coordinates in ITRF2000 but ITRF2014 with the values of 4.4 and $39.8 \mathrm{~cm}$ at KDOJ point, respectively. The discrepancy in ITRF2014 could be due to the improper datum transformation procedure. For mapping, NRTK technique is still not reliable to be adopted for determination of boundaries based on the results derived as the vector displacements for two $(5.5 \mathrm{~cm}$ and $8.1 \mathrm{~cm})$ out of three CRM exceed the allowable limit $(5 \mathrm{~cm})$. In conclusion, it is worth noting that, NRTK technique adopted for positioning should addressed a proper datum transformation process (ITRF2014 to ITRF2000) to improve quality of data meanwhile for mapping works, the NRTK technique is still unreliable to be implemented.
\end{abstract}

Keywords: MyRTKnet, SpiderNet, GDM2000, ITRF2014, post-processed 


\begin{abstract}
Abstrak
Daripada sembilan puluh enam (96) rangkaian Continuously Operating Reference Stations (CORS), Jabatan Ukur dan Pemetaan Malaysia (DSMM) telah membangunkan perkhidmatan pancaran data hakiki yang dikenali sebagai Malaysia Real-Time Kinematic GNSS Network (MyRTKnet). MyRTKnet kini beroperasi menggunakan sistem Leica SpiderNet yang dikonfigurasikan untuk memberikan koordinat kepada pengguna dalam sistem rujukan Geocentric Datum of Malaysia 2000 (GDM2000). GDM2000 merupakan datum geosentrik Malaysia, dibangunkan berdasarkan International Terrestrial Reference Frame (ITRF) 2000 atau ITRF2000. Kualiti koordinat daripada sistem MyRTKnet adalah kurang optimum kerana ITRF telah merealisasikan rangkaan yang terkini iaitu ITRF2014. Oleh itu, kajian ini dijalankan untuk menilai ketepatan dan kejituan koordinat perkhidmatan data hakiki daripada sistem MyRTKnet melalui perbandingan dengan koordinat kualiti kawalan yang dipasca-proses pada titik/stesen yang dipilih bagi tujuan penentududukan. Manakala bagi konteks pemetaan pula, koordinat daripada Network Real-Time Kinematic (NRTK) pada titik Cadastral Reference Mark (CRM) dinilai dengan nilai sebenar. Hasil kajian menunjukkan bahawa titik yang dicerap dalam ITRF2000 mempunyai anjakan sekitar $37 \mathrm{~cm}$ dari titik yang dicerap dalam ITRF2014. Hal ini disebabkan oleh pergerakan berterusan Sundaland Block. Seterusnya, melalui penilaian Teknik NRTK, tidak ada anjakan yang signifikasi bagi koordinat dalam ITRF2000 $(4.4 \mathrm{~cm})$ tetapi bagi ITRF2014, terdapat $39.8 \mathrm{~cm}$ anjakan di stesen KDOJ. Perbezaan dalam ITRF2014 mungkin disebabkan oleh prosedur transformasi data yang kurang tepat. Bagi tujuan pemetaan pula, Teknik NRTK masih belum diyakini kebolehannya untuk digunakan dalam penentuan tanda sempadan. Merujuk kepada hasil kajian, dua daripada tiga CRM mempunyai anjakan vektor melebihi had yang dibenarkan $(5 \mathrm{~cm}$ ) iaitu $5.5 \mathrm{~cm}$ dan $8.1 \mathrm{~cm}$. Kesimpulannya, teknik NRTK yang digunakan untuk penetududukan haruslah melalui proses transformasi data yang betul (ITRF2014 ke ITRF2000) bagi meningkatkan kualiti koordinat yang dicerap manakala bagi kerja-kerja pemetaan, teknik NRTK masih tidak dapat dilaksanakan.
\end{abstract}

Kata kunci: MyRTKnet, SpiderNet, GDM2000, ITRF2014, pascapemprosesan

(C) 2021 Penerbit UTM Press. All rights reserved

\subsection{INTRODUCTION}

The Malaysian continuously operating reference stations (CORS) service, known as the Malaysia RealTime Kinematic GNSS Network (MyRTKnet), provides corrections generated by the central processing facility based on the Network Real-Time Kinematic (NRTK) approaches to registered users. MyRTKnet is operated by the Geodetic Survey Division, DSMM, and is currently the central local geodetic infrastructure, primarily for horizontal control. The utilisation of NRTK enables users to conduct surveying, engineering and mapping in real-time with reliable results. Network RTK reduces the effect of distancedependent errors on the rover's computed position within the network [1]. The concept of NRTK Global Positioning System (GPS) and Global Navigation Satellite Systems (GNSS) originated in the mid-1990s [2], and its application in the survey industry is widely spreading. There are many techniques for NRTK, such as Virtual Reference Station (VRS) and Broadcast Solution (FKP), and MyRTKnet also supports the majority of these techniques. Table 1 listed down some important comparison between VRS, FKP and Master-Auxiliary Corrections (MAX).
Table 1 Comparison of NRTK techniques namely VRS, FKP and MAX

\begin{tabular}{|l|l|l|l|}
\hline \multicolumn{1}{|c|}{$\begin{array}{c}\text { NRTK } \\
\text { Techniques }\end{array}$} & \multicolumn{1}{c|}{ VRS } & \multicolumn{1}{c|}{ FKP } & \multicolumn{1}{c|}{ MAX } \\
\hline CORS & $\begin{array}{l}\text { Three } \\
\text { nearest }\end{array}$ & $\begin{array}{l}\text { Minimum } \\
\text { three }\end{array}$ & clusters \\
\hline Communication & Two ways & One way & Two ways \\
\hline Concept & $\begin{array}{l}\text { A short } \\
\text { baseline } \\
\text { of the } \\
\text { virtual } \\
\text { reference } \\
\text { station }\end{array}$ & $\begin{array}{l}\text { Inclined } \\
\text { plane } \\
\text { model for } \\
\text { spatially } \\
\text { correlated } \\
\text { errors }\end{array}$ & $\begin{array}{l}\text { Correction } \\
\text { dissemination } \\
\text { by clusters of } \\
\text { CORS }\end{array}$ \\
\hline $\begin{array}{l}\text { Simultaneous } \\
\text { Login }\end{array}$ & $\begin{array}{l}\text { Non-limited } \\
\text { limited }\end{array}$ & Non-limited \\
\hline
\end{tabular}

\subsection{Revision of the Geocentric Datum of Malaysia 2000 (GDM2000)}

GDM2000 was established with reference to International Terrestrial Reference Frame 2000 (ITRF2000) at epoch $2^{\text {nd }}$ January 2000. The Geocentric Datum of Malaysia 2000 (GDM2000) coordinates are firstly used at seventeen (17) Malaysian Active GPS System (MASS) stations, also 
known as the Zero Order Network of Malaysia [3]. On $26^{\text {th }}$ August 2003, DSMM has developed GDM2000 with the characteristic of earth-centred earth-fixed (ECEF) having the origin at the mass centre of the Earth.

Following a series of earthquakes in Indonesia, particularly in 2004, 2005 and 2007, the horizontal control networks in Malaysia has distorted. Notable displacements ranging from 1.0 to $25.8 \mathrm{~cm}$ were recorded at MYRTKnet stations during the period of $26^{\text {th }}$ December and $30^{\text {th }}$ April 2009. These displacements, among others, led to the initiative to revise the GDM2000 coordinates. Furthermore, the coordinates are also in due revision, owing to the constant plate tectonic motion [4]. This revision took place in 2009, also known as the GDM2000 (2009) coordinates.

Nevertheless, the revised coordinates are not in used by MyRTKnet system to maintain the existing datum used in the cadastre. A relationship between the existing GDM2000 and GDM2000 (2009) has been developed using a multiple regression formula to cater to those in needs of the coordinate in the upto-date datum. Table 2 summarised some of the changes in coordinate systems since the introduction of GDM2000.

Table 2 Series of GDM2000 in the past years

\begin{tabular}{|l|l|}
\hline \multicolumn{1}{|c|}{ Event } & \multicolumn{1}{c|}{ Status } \\
\hline $\begin{array}{l}\text { Development of } \\
\text { GDM2000 }\end{array}$ & $\begin{array}{l}\text { Launched in 2003 and is } \\
\text { developed based on the } \\
\text { ITRF2000 at epoch 2000.00. }\end{array}$ \\
\hline $\begin{array}{l}\text { Change from MASS to } \\
\text { MyRTKnet with added }\end{array}$ & $\begin{array}{l}\text { Un-official revision of GDM2000 } \\
\text { that led to the release of } \\
\text { GDM2000 (2006) while } \\
\text { maintaining the same ITRF and } \\
\text { epoch. }\end{array}$ \\
\hline $\begin{array}{l}\text { Earthquakes in 2004 - } \\
\text { 2007 in Indonesia }\end{array}$ & $\begin{array}{l}\text { Revision of GDM2000 that led } \\
\text { to the release of GDM2000 } \\
\text { (2009) while maintaining the } \\
\text { same ITRF and epoch. }\end{array}$ \\
\hline $\begin{array}{l}\text { Change of system at the } \\
\text { central processing facility } \\
\text { from Trimble to Leica, } \\
\text { coupled with a series of } \\
\text { earthquakes in Indonesia } \\
\text { and constant plate } \\
\text { tectonic movement }\end{array}$ & $\begin{array}{l}\text { Revision of GDM2000 that led } \\
\text { to the release of GDM2000 } \\
\text { (2016) while maintaining the } \\
\text { same ITRF and epoch. In } \\
\text { addition, a new set of } \\
\text { coordinates referring to } \\
\text { ITRF2014 is introduced for } \\
\text { processing at the central } \\
\text { processing facility. }\end{array}$ \\
\hline $\begin{array}{l}\text { Future planning } \\
\text { DSMM is currently assessing the } \\
\text { possibility of introducing a } \\
\text { more sustainable datum than } \\
\text { the existing static datum. }\end{array}$ \\
$\begin{array}{l}\text { The existing datum for } \\
\text { MyRTKnet coordinate is } \\
\text { referring to the revision made } \\
\text { in 2016, namely the GDM2000 } \\
\text { (2016). }\end{array}$ \\
\hline
\end{tabular}

Several issues concerning MyRTKnet raised by the users such as long initialisation time, float ambiguity resolution and difficulty in generating VRS data have led to the ongoing researches to identify the exact causes. One could argue that utilisation of past ITRF, i.e. ITRF2000, could also be one of the possibilities as the latest realisation of ITRF is ITRF2014. It should be noted that there have been few revisions of ITRF over the years, namely ITRF2005 and ITRF2008.

\subsection{Mapping Datum: Cadastral Reference Mark (CRM)}

When starting a cadastral survey, the first thing that is required is datum. Two possible questions are: (1) are there three old boundary stones that are welllocated, and (2) are there two old boundary stones and a solar observation carried out. These are the general practices of starting a cadastral survey and are still in used to this day.

With the initiative of DSMM to introduce e-Cadastre on $1^{\text {st }}$ May 2010 and to carry out the Coordinated Cadastral System (CCS), Cadastral Reference Mark (CRM) is introduced as a datum following the fast-spreading use of GNSS in surveying. Yusoff et al., (2013) explained that e-Cadastre is a system optimising the latest technology including GIS and survey, converting the traditional Bowditch and Transit computation into Least Square Adjustment, and transforming the current cadastral system to a Coordinated Cadastral System (CCS) [5].

CRM at the same time, aids the development of the digital cadastral database, which is known as National Digital Cadastral Database (NDCDB). CRM is permanent establishments, as depicted in Figure 1. The current NDCDB is a database of two dimensional (2D), where the information is stored in 2D planimetric coordinate [6].

e-Cadastre emphasises environment and infrastructure of cadastre, which is coordinate-based to improve the database. With series of CRM comes an infrastructure of modernisation of cadastral system implicating the satellite technology. The infrastructure is called Coordinated Cadastral Infrastructure $(\mathrm{CCI})$.

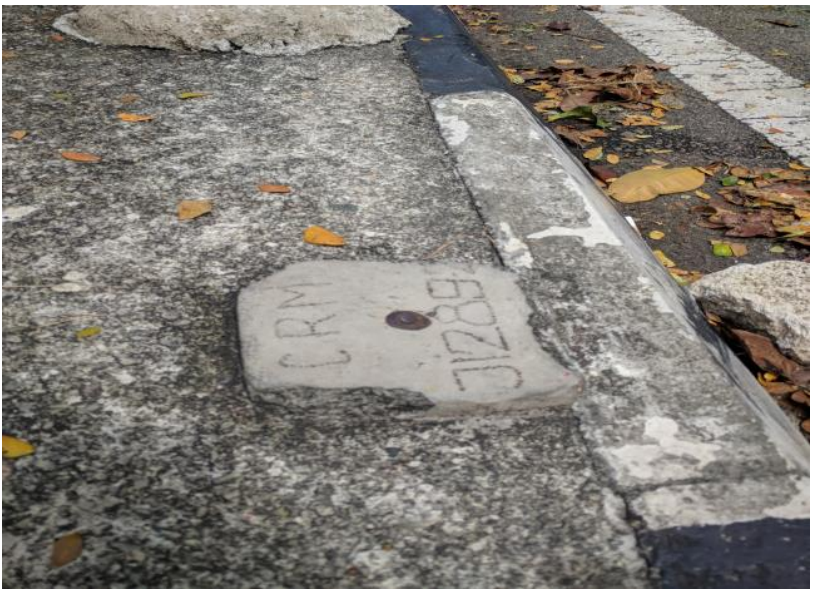

Figure 1 On-site Cadastral Reference Mark (CRM) located beside the road 


\subsection{MyRTKnet Associated Issue}

MyRTKnet is highly favourable for its versatility and time efficiency. However, there could be issues associated with the datum of the resultant coordinates from the service provided. The current configuration of MyRTKnet is customised to enable users to achieve coordinate directly in GDM2000 (based on ITRF2000) without any users' intervention, specifically used for cadastral purposes.

Nevertheless, this configuration might not be the optimal solution as GNSS satellite orbital information are broadcasted in ITRF2014. This situation might cause a mismatch between different ITRF realisations that could potentially degrade the quality of the corrections and coordinate computed by the rover receivers, since MyRTKnet provides users with coordinates in GDM2000 (ITRF2000), in contrast to GNSS satellite, where the coordinates are in ITRF2014. A possible alternative to this is to broadcast corrections in a homogeneous coordinate system (ITRF2014), allowing users to resolve the coordinate in the similar frame as the satellite orbital information. Following that, the transformation of the resultant coordinates in ITRF2014 to any other datums, e.g. GDM2000 (ITRF2000), can be made during postprocessing based on transformation parameters provided at ITRF website.

\subsection{DATA AND METHODS}

In this paper, the field works and processing strategy complements the aim of this study which is to assess the accuracy and precision of MyRTKnet real-time services. Two separate field works were conducted for positioning and mapping purposes where the data involved are RINEX GNSS data. For positioning purposes, GNSS observation was conducted at three independent points in Universiti Teknologi Malaysia (UTM) whereas for mapping purposes, GNSS observation was carried out at Kampung Melayu Majidee, Johor Bahru, involving 3 CRM. The observation techniques involved were static and NRTK (VRS) where the observed GNSS data was postprocessed using Trimble Business Center (TBC) software.

\subsection{Comparison of ITRF2000 and ITRF2014 using Static Observation}

8-hours static observation was made on the selected points as the primary or major data. The coordinates from these data processing are treated as the true values. Static observation requires at least an hour, but 8-hours observation was conducted in this case to further increase the number of satellites and their geometry, better Dilution of Precision (DOP), and several data redundancies due to the high accuracy demand for the major data. Table 3 summarises the processing strategies for the static mode.
Table 3 Processing strategies for static observation

\begin{tabular}{ll}
\hline Parameter & Descriptions \\
\hline Mode & Static \\
Observation time & 8 hours with two sessions (four hours \\
& each) \\
Interval & 10 seconds \\
Ephemeris & Broadcast \\
Satellite & GPS, GLONASS, BeiDou \\
Elevation mask & $13^{\circ}$ \\
Frequencies & Multiple \\
Solution & Fixed \\
Software & Trimble Business Center \\
\hline
\end{tabular}

The three points, namely Helipad, Kolej Dato Onn Jaafar (KDOJ), and Kolej Rahman Putra (KRP) are located at UTM. RSO geocentric projection has been selected for mapping purposes. In the 8-hours observation, two sessions were divided into 4-hours per session. As per location inside UTM, the depiction is as in Figure 2.

To better fulfil the objectives, during the processing of the network, maximum constraint of the network, fixing all CORS, was referred into two different datums. First, the maximum constraint was applied using the current GDM2000 (based on ITRF2000), and the other is in ITRF2014, which is the latest version of ITRF. Coordinates of CORS in ITRF2000 are available in the RINEX Observation File (O File) while the coordinates of the CORS in ITRF 2014 was obtained from the DSMM.

From Figure 3, Topcon GR5 receiver was used to realise the control network. It falls under the survey type receiver. Measurement for the instrument height was the antenna phase centre, in which three measurements were taken to obtain the average of slant range for further computation of vertical range.

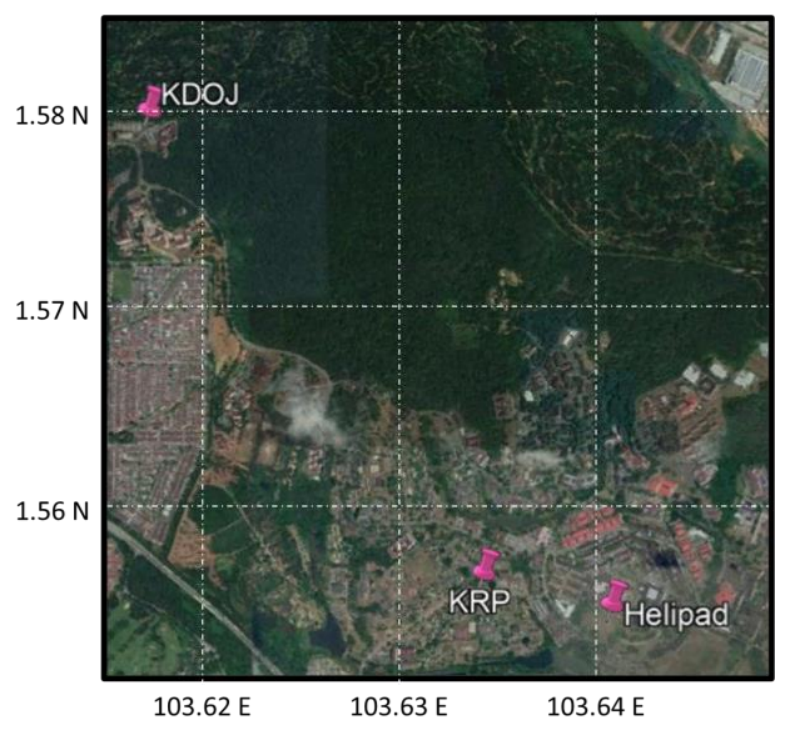

Figure 2 Locations of Helipad, KDOJ, and KRP points at UTM 


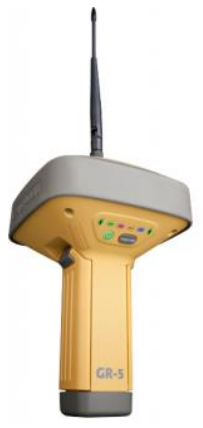

Figure 3 Topcon GR5 receiver
2.2 Network Real-Time Kinematic (NRTK) for Positioning Purposes

Still, in the same context of positioning, NRTK observations were made on these three points inside UTM. An epoch of one second interval with five times re-initialisation (to produce five epochs) were made for each point. Before giving the average coordinate, the system was set to five times datalogging before the next initialisation. The coordinates obtained using NRTK technique were set to RSO Geocentric. JHJY, KUKP, and SPGR are the CORS used for both static and NRTK mode as they are the nearest CORS available around the site.

Figure 4 illustrates the distribution of the CORS of MyRTKnet in Johor where the points of Helipad, KDOJ, and KRP are located inside the UTM area within the polygon. The nearest or the shortest baseline formed was from UTM to JHJY station giving an insight into the selection of master station for the NRTK mode (VRS) (refer Table 4).

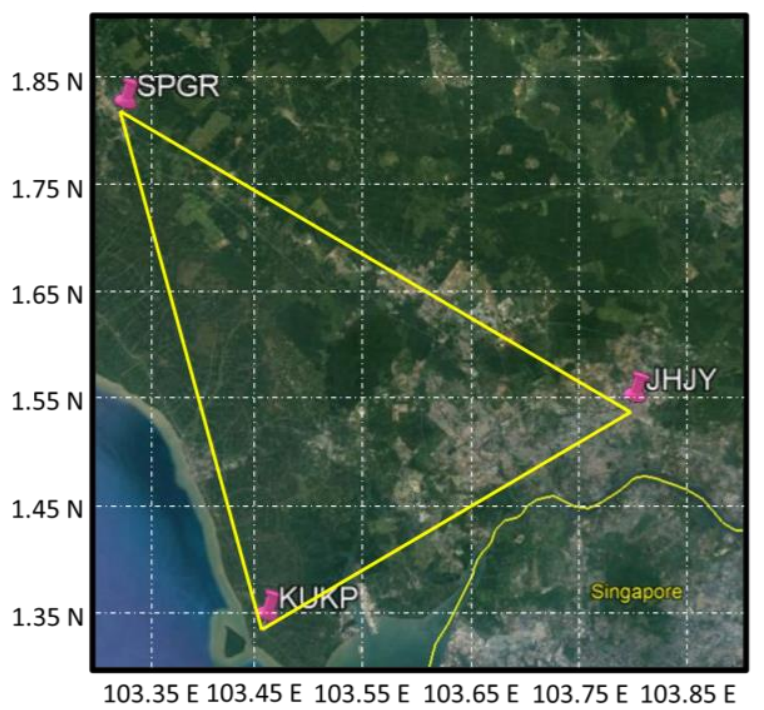

Figure 4 Stations around UTM including CORS of (SPGR, KUKP and JHJY)
Table 4 Baseline length in $\mathrm{km}$ between points at Helipad, KDOJ, KRP and CORS stations

\begin{tabular}{cccc}
\hline & JHJY & KUKP & SPGR \\
\hline Helipad & 17.91 & 32.22 & 44.92 \\
KDOJ & 20.10 & 32.68 & 42.20 \\
KRP & 18.44 & 31.97 & 44.42 \\
\hline
\end{tabular}

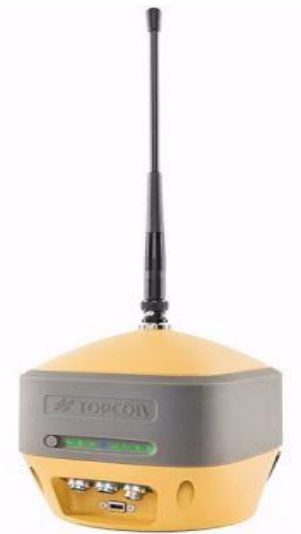

Figure 5 Topcon Hiper HR receiver

NRTK (VRS) observation technique was conducted using Topcon Hiper HR GNSS receiver as in Figure 5. The GNSS observations were conducted at both points inside UTM (positioning purpose) and CRM (cadastral purpose). The reason of using this receiver is due to its capability in using other kinds of NRTK techniques besides VRS as it is also the latest model from Topcon receiver with the latest firmware.

\subsection{Network Real-Time Kinematic (NRTK) on Cadastral Reference Mark (CRM)}

On the other hand, for mapping purpose, the observation was conducted at cadastre lot to reflect the real mapping work. As we know, before initiating any cadastral jobs, a datum is the first and foremost to be established, but for e-Cadastre, Cadastral Reference Mark (CRM) plays a big role in the satellite era as a datum besides boundary stones and solar observation.

Three nearby CRM were selected near the Masjid Kampung Melayu lot. As for the information on the CRM (coordinates), they were downloaded from the DSMM website called JUPEM2U Johor. Hence, DSMM provided CRM with coordinates with different projections. In order to carry out the mapping objective, NRTK method utilised one-second interval with five re-initialisations to produce five epochs. The Topcon GNSS receiver, namely Hiper HR, as shown in Figure 5, was used for the newly induced NRTK techniques alongside the SpiderNet initiative such as Max and iMax.

Three CRM around the lot illustrated in Figure 6 has the file name of J01289_2, J01289_3, and J01289_4. Each of these has its own Cassini Geocentric coordinates as cadastral mapping is in this projection. 


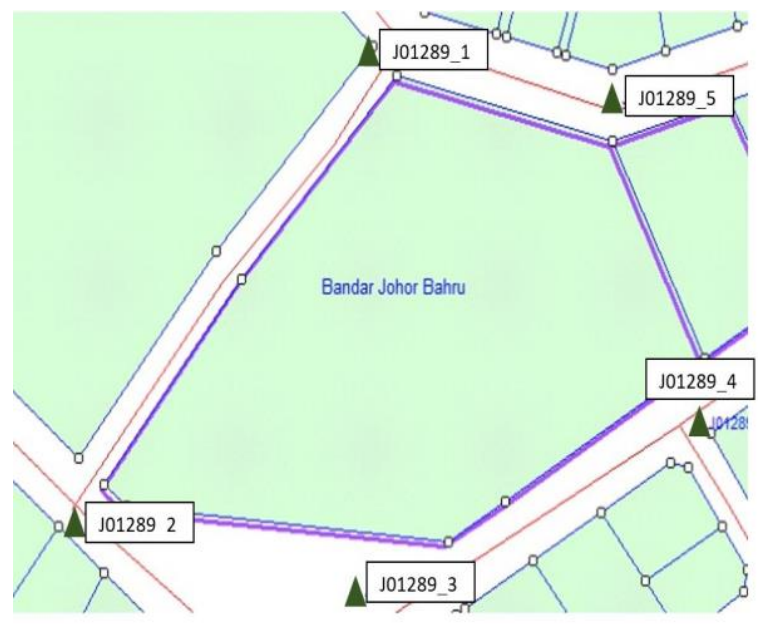

Figure 6 Location of three CRM around Masjid Kampung Melayu lot obtained from JUPEM2U Johor

\subsection{RESULTS AND DISCUSSION}

\subsection{Static Post-Processing}

GNSS data obtained from the 8-hours static observation at Helipad, KDOJ, and KRP points connected to JHJY, KUKP and SPGR stations were processed using TBC software where the session was divided into two of 4 -hours observation period. The coordinates were derived in ITRF2000 and ITRF2014, with GDM2000 at the reference datum. The errors for horizontal components deviate from 4 to $5 \mathrm{~mm}$ where the error for vertical component ranges from 27 to $33 \mathrm{~mm}$ for both coordinates in two different frames. The result for vertical component is acceptable as the height information in a GPS measurement is determined two to three times worse than the horizontal coordinates information as satellite configuration is more appropriate for horizontal coordinate determination [7]. The coordinates of Helipad, KDOJ, and KRP in RSO geocentric with respect to GDM2000 (ITRF2000) are tabulated in Table 5, followed by the coordinates of the same three points in GDM2000 (ITRF2014) in Table 6. The purpose of having static observation is to obtain the true value since they are the control points. Since static method produces the most precise results among these techniques, all the comparisons in terms of local coordinates at each station were made against static survey results [8].

Table 5 Adjusted RSO geocentric coordinates in GDM2000 (ITRF2000)

\begin{tabular}{ccccccc}
\hline Points & Easting $(\mathbf{m})$ & $\begin{array}{c}\text { Easting } \\
\text { Error }(\mathbf{m})\end{array}$ & Northing $\mathbf{( m )}$ & $\begin{array}{c}\text { Northing } \\
\text { Error }(\mathbf{m})\end{array}$ & $\begin{array}{c}\text { Ellipsoidal } \\
\text { Height }(\mathbf{m})\end{array}$ & $\begin{array}{c}\text { Ellipsoidal Height } \\
\text { Error }(\mathbf{m})\end{array}$ \\
\hline Helipad & 626723.137 & 0.005 & 172321.969 & 0.004 & 42.076 & 0.027 \\
KDOJ & 624840.243 & 0.005 & 174316.303 & 0.005 & 52.278 & 0.033 \\
KRP & 626207.757 & 0.005 & 172446.512 & 0.005 & 33.248 & 0.029 \\
\hline
\end{tabular}

Table 6 Adjusted RSO geocentric coordinates in GDM2000 (ITRF2014)

\begin{tabular}{ccccccc}
\hline Points & Easting $(\mathbf{m})$ & $\begin{array}{c}\text { Easting } \\
\text { Error }(\mathbf{m})\end{array}$ & Northing $(\mathbf{m})$ & $\begin{array}{c}\text { Northing } \\
\text { Error }(\mathbf{m})\end{array}$ & $\begin{array}{c}\text { Ellipsoidal } \\
\text { Height }(\mathbf{m})\end{array}$ & $\begin{array}{c}\text { Ellipsoidal Height } \\
\text { Error }(\mathbf{m})\end{array}$ \\
\hline Helipad & 626723.486 & 0.005 & 172321.839 & 0.004 & 42.076 & 0.027 \\
KDOJ & 624840.593 & 0.005 & 174316.172 & 0.005 & 52.278 & 0.033 \\
KRP & 626208.106 & 0.005 & 172446.380 & 0.005 & 33.247 & 0.029 \\
\hline
\end{tabular}

3.2 Coordinate Comparison of Static PostProcessing in ITRF2000 and ITRF2014

Table 7 shows the differences in horizontal and vertical means between the two different datums. Both datums are geocentric, but in terms of horizontal components, the magnitude of differences ranges from 37.2 to $37.4 \mathrm{~cm}$. On the other hand, the difference in height seems to be small. The only difference is at KRP points, which only differs about $0.1 \mathrm{~cm}$.

The significant differences between ITRF2000 and ITRF2014 in the horizontal component are expected, predominantly because they are referring to different epochs of coordinates. The former is obtained directly from Bernese GNSS data processing and is referring to epoch $2^{\text {nd }}$ January 2000, whereas the latter is computed from a datum transformation using parameters derived from a set of fiducial stations.

The large contribution is from the constant movement of Sundaland Block where all these stations are situated with the movement of approximately a few centimetres per year since 2004 [9]. It is also for this reason that the up component is less affected compared to the horizontal component. 
Table 7 Magnitude, direction, and height differences between ITRF2000 and ITRF2014

\begin{tabular}{ccccc}
\hline Points & Magnitude $(\mathbf{m})$ & Bearing & Direction & Height Difference $(\mathbf{m})$ \\
\hline Helipad & 0.372 & $290^{\circ} 25^{\prime} 48.01^{\prime \prime}$ & North-west & 0.000 \\
KDOJ & 0.374 & $290^{\circ} 31^{\prime} 12.56^{\prime \prime}$ & North-west & 0.000 \\
KRP & 0.373 & $290^{\circ} 34^{\prime} 26.52^{\prime \prime}$ & North-west & 0.001 \\
\hline
\end{tabular}

\subsection{Time Series Analysis of NRTK using VRS}

Results from the observation using VRS NRTK are plotted in time series scattering to study the stability of the coordinates given by the server in one day. At periodic points of time, collecting data through observation of a response variable is called a time series [10]. Figures 7 to 9 are the time series analysis of the Helipad, KDOJ, and KRP points at 8.00 a.m., 12 p.m., and 6 p.m. The overall trend of precision tends to deteriorate as the time increases. Note that the smaller the standard deviation, the higher the precision is. The degradation starts for every point when entering the evening phase. As depicted in Figures 7 to 9, the up component rose from $0.007 \mathrm{~m}$ at 12 p.m. to $0.044 \mathrm{~m}$ at 6 p.m. showing a tremendous degradation in the evening.

Precision wise, vertical component seems to show the most deterioration among other horizontal components. One of the challenges when using any GNSS technique is the mitigation of tropospheric effects [11]. Tropospheric effects contribute to the up-component deteriorations. Hence, compared to the horizontal, the vertical demonstrates a bigger loss of precision due to these distance-dependent errors.

Assessing the NRTK (VRS) observation at three points, KRP point gives the worst precision among them where the overall precision ranges from $0.038 \mathrm{~m}$ up to $0.032 \mathrm{~m}$ for horizontal and vertical components. This is due to the location of the point where it is located near to a tree causing obstruction towards the observed data known as multipath error (refer Figure 10).

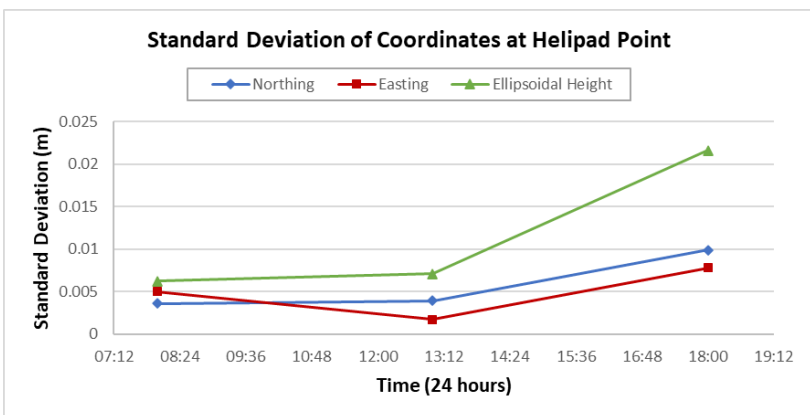

Figure 7 Standard deviation of coordinates at Helipad point observed using VRS

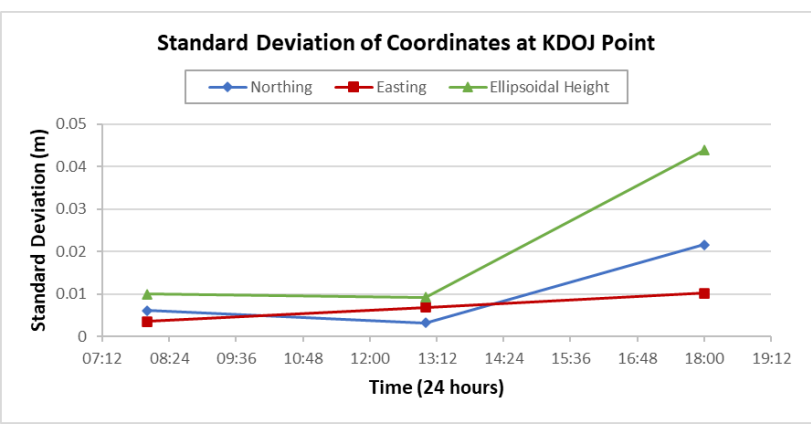

Figure 8 Standard deviation of coordinates at KDOJ point observed using VRS

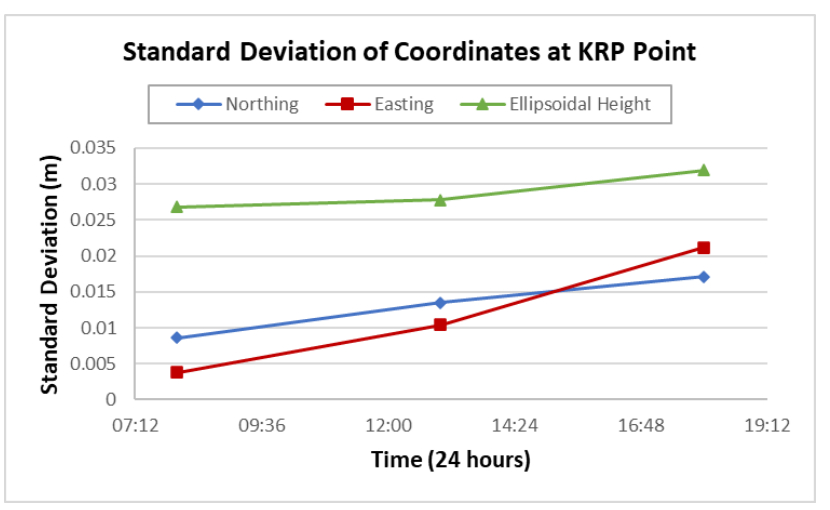

Figure 9 Standard deviation of coordinates at KRP point observed using VRS
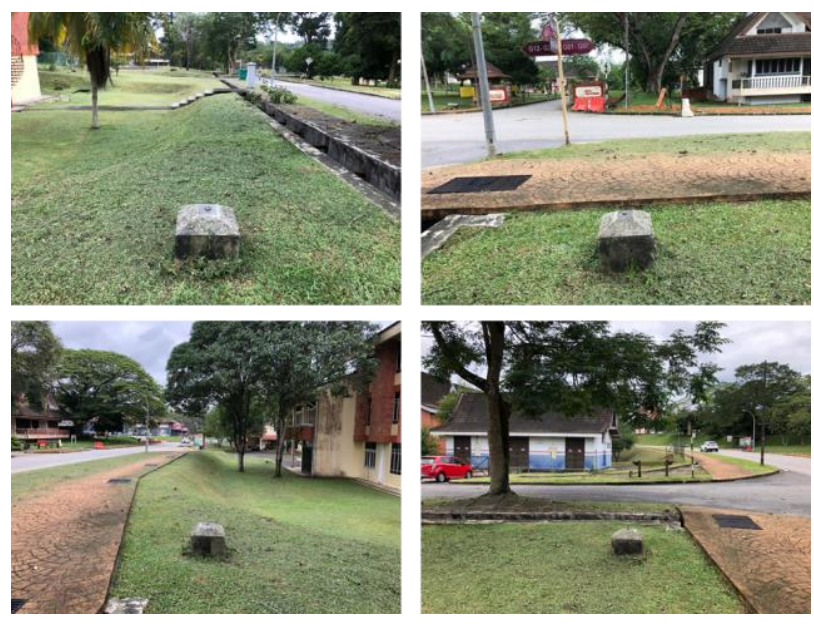

Figure 10 Location of KRP point near to the tree 


\subsection{Coordinate Comparison of Static Post- Processing and NRTK in ITRF2000}

The coordinates from an 8-hours of GNSS static observation and NRTK techniques were derived in ITRF2000. Both techniques are compared in terms of differences in magnitude, direction, and height, as well as their Root Mean Square Error (RMSE) of each component for every point. Referring to Table 8 , the differences in magnitude range between 2.3 to 4.4 $\mathrm{cm}$. These differences are within $\mathrm{cm}$ level, but the highest value is at KDOJ point $(4.4 \mathrm{~cm})$ is of concern as the allowable horizontal tolerance for the majority of precise applications such as property boundary analysis, engineering works and change detection are typically below $2 \mathrm{~cm}$. However, since the NRTK technique is compared to static, the achievable accuracy is expected to be up to $5 \mathrm{~cm}$ due to short observation data in modelling distance-dependent errors [12].

The differences in height between points observed using static and NRTK techniques vary from 7 to $10.3 \mathrm{~cm}$ with the highest value at KRP due to its location followed by Helipad and KDOJ points. Even though, the accuracy of height component is bigger than horizontal component, it is still acceptable as the altitude error is always considerably worse than horizontal, except for KRP point. The major contribution of this height difference might probably due to the multipath error. It should also be noted that the distance-dependent errors such as ionospheric and tropospheric delay might cause the increase of vertical error in NRTK up to $7 \mathrm{~cm}$ [12], but less so in the post-processed static observation.

Another contribution to the large deviation in the vertical component might be due to the fact that the post-processing using TBC utilises multiple frequencies instead of dual frequency, which can eliminate the distance-dependent error. While dual frequency measurements can eliminate most of the ionospheric error contributions, tropospheric effects are attempted to be compensated by adopting a suitable model [13] as operated using NRTK technique.

Based on Table 9, the accuracy of NRTK using VRS to the control points established using static observation shows the smallest number at KRP for northing component with the value of $2.1 \mathrm{~cm}$, whereas KDOJ has the lowest accuracy with the value of $4.3 \mathrm{~cm}$. For the easting, Helipad has the highest accuracy at $0.6 \mathrm{~cm}$. As for height component, KDOJ shows a very promising result with $7.1 \mathrm{~cm}$ accuracy, followed by Helipad and KRP points reflecting almost the same values of height differences in Table 8.

Table 8 Magnitude, direction and height differences between static and NRTK techniques in ITRF2000

\begin{tabular}{ccccc}
\hline Points & Magnitude $(\mathbf{m})$ & Bearing & Direction & Height Difference $(\mathbf{m})$ \\
\hline Helipad & 0.030 & $350^{\circ} 32^{\prime} 41.9^{\prime \prime}$ & North-west & 0.090 \\
KDOJ & 0.044 & $348^{\circ} 38^{\prime} 18.9^{\prime \prime}$ & North-west & 0.070 \\
KRP & 0.023 & $30^{\circ} 21^{\prime} 51.4^{\prime \prime}$ & North-west & 0.103 \\
\hline
\end{tabular}

Table 9 RMSE between static and NRTK techniques in ITRF2000

\begin{tabular}{cccc}
\hline Points & RMSE Northing $(\mathbf{m})$ & RMSE Easting $(\mathbf{m})$ & RMSE Height $(\mathbf{m})$ \\
\hline Helipad & 0.030 & 0.006 & 0.090 \\
KDOJ & 0.043 & 0.009 & 0.071 \\
KRP & 0.021 & 0.012 & 0.104 \\
\hline
\end{tabular}

\subsection{Coordinate Comparison of Static Post- Processing (ITRF2014) and NRTK in ITRF2000}

Based on Table 10, the magnitude shows enormous discrepancies between coordinates obtained from static and NRTK techniques which is up to tens of centimetres. Horizontally, KDOJ point observed using NRTK (ITRF2000) technique deviates $39.8 \mathrm{~cm}$ away from the same point derived using static postprocessing in ITRF2014 marking the highest difference among the other two points. KRP point demonstrates the lowest magnitude of $37 \mathrm{~cm}$, followed by Helipad with the value of $38.8 \mathrm{~cm}$. As stated before, these differences are expected and can be attributed to the improper datum transformation applied during derivation of coordinates using NRTK technique. This discrepancy might happen due to the different frames used to generate network corrections from server (ITRF2014), where users received coordinates with fix stations in ITRF2000. Meanwhile, the vertical differences seem to be less significant as the highest difference is only $10.2 \mathrm{~cm}$ for KRP. The smallest difference in height accuracy at KDOJ point is $7 \mathrm{~cm}$, followed by Helipad with $9 \mathrm{~cm}$ where these three values are almost similar compared to Table 8 . The conflict of improper datum transformation applied during coordinate derivation using NRTK technique is less affected at vertical component compared to horizontal component as the values of RMSE (refer Table 11) are consistent.

As tabulated in Table 11, RMSE between static and NRTK techniques shows that the horizontal accuracy is worse compared to vertical accuracy with the significant values at easting which range from 33.7 to $35.9 \mathrm{~cm}$. The values of RMSE at northing deviates from 15.1 to $17.4 \mathrm{~cm}$ whereas for height 
components the RMSE values are $7.1,9$ and $10.3 \mathrm{~cm}$ at KDOJ, Helipad and KRP points, respectively. Apart from inadequate datum transformation, the accuracy of NRTK technique would also contribute to error in the solution as well with the differences in magnitude of up to $5 \mathrm{~cm}$ for horizontal and $7 \mathrm{~cm}$ for vertical components [12].

Furthermore, based on research conducted by Jaffar et al., (2019), the average movement of
MyRTKnet stations in magnitude is $34.6 \mathrm{~cm}$ from GDM2000 (ITRF2000) to GDM2000 (ITRF2014) indicating that the differences between frames is bigger in horizontal direction [14]. Zulkifli et al., (2019) have also stated in their study of the impact of different frames on positioning and mapping in Malaysia, that the distance of coordinate point derived using ITRF2000 and ITRF2014 is approximately more than $30 \mathrm{~cm}[15]$.

Table 10 Magnitude, direction and height differences between static (ITRF2014) and NRTK (ITRF2000) techniques

\begin{tabular}{ccccc}
\hline Points & Magnitude $(\mathbf{m})$ & Bearing & Direction & Height Difference $(\mathbf{m})$ \\
\hline Helipad & 0.388 & $294^{\circ} 21^{\prime} 30.4^{\prime \prime}$ & North-wes & 0.090 \\
KDOJ & 0.398 & $295^{\circ} 51^{\prime} 27.8^{\prime \prime}$ & North-wes & 0.070 \\
KRP & 0.370 & $30^{\circ} 21^{\prime} 51.4^{\prime \prime}$ & North-west & 0.102 \\
\hline
\end{tabular}

Table 11 RMSE between static (ITRF2014) and NRTK (ITRF2000) techniques

\begin{tabular}{cccc}
\hline Points & RMSE Northing $(\mathbf{m})$ & RMSE Easting $(\mathbf{m})$ & RMSE Height $(\mathbf{m})$ \\
\hline Helipad & 0.160 & 0.353 & 0.090 \\
KDOJ & 0.174 & 0.359 & 0.071 \\
KRP & 0.151 & 0.337 & 0.103 \\
\hline
\end{tabular}

\subsection{Coordinate Comparison of Known CRM and NRTK}

From the NRTK (VRS) observation technique, coordinates at three CRM (J01289_2, J01289_3, and J01289_4) were derived to assess the reliability of provided MyRTKnet real-time services for mapping purposes. Regarding to Table 12, the CRM of J01289_4 shows the lowest displacement in terms of magnitude between coordinates observed using NRTK technique and obtained from NDCDB at JUPEM2U Johor, followed by J01289_2 and J01289_3. Both mapping coordinates are in Cassini Geocentric with the magnitude displacement of 2.8, 5.4, and 8.1 $\mathrm{cm}$ at the respective CRMs. For the differences in height, J01289_4 also shows the least discrepancy 15 $\mathrm{cm}$ ) compared to the other two CRM (J01289_3: 6.4 $\mathrm{cm}$ and J01289_2: $8 \mathrm{~cm}$ ) indicating a good observation data at J01289_4. Generally, for cadastral works, these results conclude that it is unreliable to adopt NRTK technique as the magnitude obtained for two out of three CRM exceeds the allowable vector displacement which is $5 \mathrm{~cm}$ for CRM located at urban areas [16].

From the RMSE tabulated in Table 13, CRM J01289_4 shows the highest accuracy at both horizontal and vertical components with values of 2.3 (N), 1.7 (E), and $4.9 \mathrm{~cm}$ (U) followed by J01289_2 and J01289_3 for the accuracy of horizontal component and J01289_3 and J01289_2 for vertical component.
As mentioned in the section 3.1, horizontal accuracy is always two to three times better than vertical accuracy reflecting a better coordinate quality at horizontal plane.

Cadastral works urge the high precision coordinates for the determination of the boundaries. Hence, if the NRTK technique was to be implemented, its accuracy must first be improved. Factor that can be included to improve the accuracy of the coordinates obtained is the quality of the GNSS receiver in terms of its ability to receive at least dual-frequency signal and observe at least six GNSS satellites simultaneously for the real-time technique. Furthermore, observation procedures for cadastral works should also be taken into account to increase the precision of the data observed such as the number of observation epoch is two (ten readings for every five seconds to produce one observation epoch) for every point (through two different initialisation and re-initialisation process), the value of position dilution of precision (PDOP) below five and the tolerance within two epochs are $2 \mathrm{~cm}$ and $6 \mathrm{~cm}$ for horizontal and vertical components, respectively [16]. Additionally, it is encouraged to use geodetic type antenna in order to minimise the effects of electrical phase centre variations and multipath error. However, for integrated receiver, survey-grade antenna is already sufficient for cadastral works.

Table 12 Magnitude, direction and height differences between CRM (NDCDB) and NRTK in Cassini Geocentric

\begin{tabular}{ccccc}
\hline Points & Magnitude $(\mathbf{m})$ & Bearing & Direction & Height Difference $(\mathbf{m})$ \\
\hline J01289_2 & 0.054 & $82^{\circ} 43^{\prime} 142^{\prime \prime}$ & North-east & 0.080 \\
J01289_3 & 0.081 & $60^{\circ} 19^{\prime} 31.7^{\prime \prime}$ & North-east & 0.064 \\
J01289_4 & 0.028 & $36^{\circ} 13^{\prime} 56.71^{\prime \prime}$ & North-east & 0.050 \\
\hline
\end{tabular}


Table 13 RMSE between CRM (NDCDB) and NRTK in Cassini Geocentric

\begin{tabular}{cccc}
\hline Points & RMSE Northing $(\mathbf{m})$ & RMSE Easting $(\mathbf{m})$ & RMSE Height $(\mathbf{m})$ \\
\hline J01289_2 & 0.008 & 0.054 & 0.081 \\
J01289_3 & 0.040 & 0.070 & 0.065 \\
J01289_4 & 0.023 & 0.017 & 0.049 \\
\hline
\end{tabular}

\subsection{CONCLUSION}

As comprehensively discussed in this paper, the realtime service provided by MyRTKnet namely NRTK (VRS) was successfully assessed in terms of accuracy and precision for positioning and mapping purposes in Malaysia. Due to the constant movement of Sundaland Block, the observed points move approximately $37 \mathrm{~cm}$ in north-west direction from the observation in ITRF2000 to ITRF2014 frames. Undoubtedly, the differences in coordinates derived from static and NRTK techniques in ITRF2000 show smaller vector displacements compared to coordinates in ITRF2014 with the maximum values of $4.4 \mathrm{~cm}$ and $39.8 \mathrm{~cm}$ at KDOJ point, respectively. The discrepancy in ITRF2014 frame could be due to the improper datum transformation procedure. Arguably, better results could be expected if the datum transformation procedure (from ITRF2014 to ITRF2000) is performed before the resolution of coordinate at user rover (NRTK) in order to preserve the consistency with the orbital information from GNSS satellites.

In terms of mapping purposes, the new coordinate values were observed at CRM using NRTK technique and compared to the known coordinate from NDCDB. Since both coordinates are in Cassini Geocentric system (ITRF2000), the discrepancy in vector should be less than $5 \mathrm{~cm}$ (urban areas) as derived at CRM J01289_4 $(2.8 \mathrm{~cm})$. However, the accuracy of other points can still be improved by taking into account the factors mentioned in section 3.6. As the other two CRM exceed the allowable displacement, generally, it is not reliable to adopt the NRTK technique for determination of boundaries.

To briefly summarise, in order to implement NRTK technique provided by MyRTKnet for positioning, a proper process of datum transformation (ITRF2014 to ITRF2000) involving seven transformation parameters should be addressed prior fixing the coordinates to improve the quality of data obtained. Meanwhile for mapping purposes, since a fix geocentric datum must be opted (Cassini Geocentric in ITRF2000), the issue on datum determination can be disregarded. However, to implement NRTK technique for cadastral work, many factors must first be considered.

\section{Acknowledgement}

The author fully acknowledges Universiti Teknologi Malaysia for the approved permission, which makes this important research viable and effective. Special thanks to the Department of Survey and Mapping
Malaysia (DSMM) for providing the necessary assistance that led to the success of this research. This project is funded by the Ministry of Education (MOE) Malaysia and Universiti Teknologi Malaysia under the Research University Grant (RUG) Tier 2, Vote Number Q.J130000.2652.16J88.

\section{References}

[1] Berber, M. and Arslan, N. 2013. Network RTK: A Case Study in Florida. Measurement. 46(8): 2798-2806.

[2] Rizos, C. 2002. Network RTK Research and Implementation: A Geodetic Perspective. Journal of Global Positioning Systems. 1(2): 144-150.

[3] Kadir, M., Ses, S., Omar, K., Desa, G., Omar, A. H., Taib, K. and Nordin, S. 2003. Geocentric Datum GDM2000 for Malaysia: Implementation and Implications. In Seminar on GDM2000, 28 August 2003. Department of Survey and Mapping Malaysia, Kuala Lumpur, Malaysia.

[4] Gill, J., Shariff, N. S., Omar, K. M., Din, A. H. M. and Amin, Z. M. 2016. Development of a Time-dependent 3-parameter Helmert Datum Transformation Model: A Case Study for Malaysia. International Archives of the Photogrammetry, Remote Sensing and Spatial Information Sciences XLII4/WI. 181-189.

[5] Yusoff, M. Y. M., Jamil, M. H. and Halim, M. N. Z. A 2013. Ekadaster: A Learning Experience for Malaysia. FIG Pacific Small Island Developing States Symposium on Policies and Practices for Responsible Governance. 18-20 September 2013. Suva, Fiji.

[6] Choon, T. L, and Seng, L. K 2013. Developing Infrastructure Framework for 3D Cadastre. FIG Congress 2014 on Engaging the Challenges - EnhancingtThe Relevance. 1621 June 2014. Kuala Lumpur, Malaysia.

[7] Berber, M., Ustun, A. and Yetkin, M. 2012. Comparison of Accuracy of GPS Techniques. Measurement. 45(7): 17421746.

[8] Department of Survey and Mapping Malaysia (DSMM). 2016. Perkhidmatan MyRTKnet di bawah Platform SpiderNet. Pekeliling Ketua Pengarah Ukur dan Pemetaan Bilangan 1/2016. Kuala Lumpur.

[9] Jhonny, J. 2010. Post-seismic Earthquake Deformation Monitoring in Peninsular Malaysia using Global Positioning System. Master of Science. Universiti Teknologi Malaysia, Skudai.

[10] Sincich, T. 1996. Business Statistics by Example. $5^{\text {th }}$ ed. Prentice-Hall.

[11] Edwards, S. J., Clarke, P. J., Penna, N. T. and Goebell, S. 2010. An Examination of Network RTK GPS Services in Great Britain. Survey Review. 42(316): 107-121.

[12] Tiryakioglu, I., Ugur, M. A., Solak, H. I and Safak, S. 2019. Examining the Accuracy of Network RTK and Long Base RTK Methods with Repetitive Measurements. Journal of Sensors. 2019: 1-12.

[13] Harikumar, G., Karthikeyan, K., Syamala, S., Pillai, C. R., Hemachandran, S., Shukkoor, A. A. and Mohanlal, P. P. 2013. Troposphere Induced GPS Navigation Error, Its Effect on GPS-INS Integrated System Performance and Mitigation Strategies. Indian Journal of Radio and Space Physics. 42: 150-158. 
[14] Jaffar, N. J., Musa, T. A, and Aris, W. A. W. 2019 Assessment of Geocentric Datum of Malaysia 2000 (GDM2000). The International Archives of the Photogrammetry, Remote Sensing and Spatial Information Sciences, XLII-4/W16. 271-276.

[15] Zulkifli, N. A., Din, A. H. M. and Omar, A. H. 2019. The Impact of Different International Terrestrial Reference
Frames (ITRFs) on Positioning and Mapping in Malaysia. In Pradhan, B. (Ed.). Lecture Notes in Civil Engineering (pp. 671-690). Singapore: Springer

[16] Jabatan Ukur dan Pemetaan Malaysia. 2009. Garis Panduan Amalan Kerja Ukur Kadaster dalam Persekitan eKadaster. Pekeliling Ketua Pengarah Ukur dan Pemetaan Bilangan 6/2009. Kuala Lumpur. 